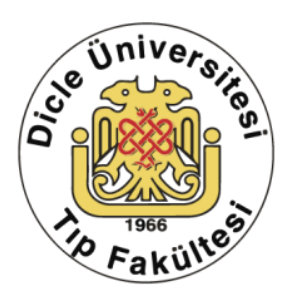

\title{
Subklinik hipotroidi hasta serumlarında homosistein ve irisin seviyelerinin tanısal öneminin belirlenmesi
}

\author{
Diler Us Altay' ${ }^{1}$ Ozlem Ozdemır², Tevfik Noyan ${ }^{3}$, Sefa Yuksel ${ }^{4}$, Burhanettin Sertaç Ayhan ${ }^{5}$ \\ 1 Ordu Üniversitesi, Sağllk Bilimleri Fakültesi, Beslenme ve Diyetetik Bölümü, Ordu, Türkiye ORCID: 0000-0002-0465-8403 \\ 2 Ordu Üniversitesi Tıp Fakültesi, Dahiliye ABD. Ordu, Türkiye ORCID: 0000-0001-5088-4316 \\ 3 Ordu Üniversitesi Tıp Fakültesi Tıbbi Biyokimya ABD. Ordu, Türkiye ORCID: 0000-0002-7733-0177 \\ 4 Ordu Üniversitesi Tıp Fakültesi Tıbbi Biyokimya ABD. Ordu, Türkiye ORCID: 0000-0002-5863-1775 \\ 5 Ordu Üniversitesi Tıp Fakültesi Tıbbi Biyokimya ABD. Ordu, Türkiye ORCID: 0000-0002-1915-1306 \\ Geliş: 27.06.2019; Revizyon: 04.11.2019; Kabul Tarihi: 06.11.2019
}

$\ddot{0} \mathbf{z}$

Amaç: $\mathrm{Bu}$ çalışmanın amacı, subklinik hipotiroidi (SH) hastalarının serumlarında irisin ve homosistein (Hcy) düzeylerinin tanısal önemini belirlemektir.

Yöntemler: Çalışmada 80 kişi değerlendirildi. Hasta grubuna, SH tanısı konmuş 40 hasta ve kontrol grubuna 40 sağlıklı birey dahil edildi. Kan örnekleri toplandı ve enzim bağlı immünosorbent testi (ELISA) kullanılarak serum irisin ve Hcy düzeyleri belirlendi. Tiroid uyarıcı hormon (TSH), serbest triiyodotironin (fT3), serbest tiroksin (fT4) düzeyleri Cobas e 601 otoanalizörü kullanılarak kemilüminesans yöntemiyle ölçüldü.

Bulgular: SH hastalarında Irisin, Hcy, TSH düzeyleri kontrol grubuna göre anlamlı olarak yüksek bulundu (sırasıyla $\mathrm{p}=$ $0.0001, p=0.0001, p=0.0001$ ). Ayrıca, İrisin ve Hcy seviyeleri TSH seviyeleri kadar spesifik ve sensitifti. SH için en iyi kesme noktaları, İrisin için > $14.43 \mathrm{ng} / \mathrm{mL}$, Hcy için > $13.53 \mathrm{nmol} / \mathrm{ml}$ ve TSH için > $4.11 \mathrm{uUI} / \mathrm{mL}$ idi.

Sonuç: Irisin, Hcy SH için tanısal bir biyobelirteç olarak kullanılabilir.

Anahtar kelimeler: irisin, homosistein, subklinik hipotiroidi, TSH

DOI: $10.5798 /$ dicletip

Yazışma Adresi / Correspondence: Diler Us Altay, Ordu Üniversitesi, Sağllk Bilimleri Fakültesi, Beslenme ve Diyetetik Bölümü, Ordu, Türkiye e-mail: surelid@hotmail.com 


\title{
Determining the diagnostic significance of irisin and homocysteine levels in the serum of patients with subclinical hypothyroidism
}

\begin{abstract}
Objectives: The aim of this study was to determine the diagnostic significance of irisin and homocysteine (Hcy) levels in the serum of patients with subclinical hypothyroidism (SH).

Methods: In the study, 80 individuals were evaluated. The patient group included 40 subjects diagnosed with SH and the control group 40 healthy individuals. Blood specimens were collected and serum irisin and Hcy levels were determined using enzyme-linked immunosorbent assay (ELISA). Thyroid stimulating hormone (TSH), free triiodothyronine (fT3), free thyroxine (fT4) levels were measured by chemiluminescent method using Cobas e 601 autoanalyzer

Results: Irisin, Hcy and TSH levels in SH patients were significantly higher compared with the control group ( $p=0.0001, p=0.0001, p=0.0001$, respectively). Also, irisin and hcy levels were closely sensitive and specific even TSH levels. The best cut-off points for irisin were $>14.43 \mathrm{ng} / \mathrm{mL}$, hcy were $>13.53 \mathrm{nmol} / \mathrm{mL}$, TSH $>4.11 \mu \mathrm{UI} / \mathrm{mL}$ for SH .

Conclusion: Irisin and Hcy may be used as a diagnostic biomarker for $\mathrm{SH}$.
\end{abstract}

Keywords: irisin, homocysteine, subclinical hypothyroidism, TSH.

\section{GíRIŞ}

Subklinik hipotiroidizm (SH) genel popülasyonda, özellikle orta yaşlı ve yaşlı hastalarda yaygin bir hastalıktır. Normal değerde tiroksin (T4) ve triiyodotironin (T3) ve artmış seviyede tiroid uyarıcı hormon (TSH) durumunu yansitır ${ }^{1}$. Fibronektin tip III domaini içeren protein 5 (FDNC5) bir tip I membran proteini olup, peroksizom proliferatörleriyle aktifleștirilen reseptör gama koaktivatör-1 alfa (PGC1a) aracılığıyla ile düzenlenir. FNDC5, bilinmeyen bir proteaz ile kesilir ve ekstraselüler kısmı olan irisin, kan dolaşımına salınır ${ }^{2}$. FNDC5 proteini birçok dokuda olduğu gibi tiroid dokusunda da eksprese edilir ${ }^{3,4}$. İrisin miyokini, enerji metabolizmasında önemli bir role sahiptir. Bazal metabolizma hızını ve enerji tüketimini artırır ve bu durum kilo kaybı ile sonuçlanır. İrisin, beyaz yağ dokusunun kahverengileşmesini uyarır ve onu bej forma dönüștürür ${ }^{5,6}$. İrisin anoreksiya nervoza, metabolik sendrom, obezite, kronik böbrek hastalığı, insülin direnci, hipotiroidizm ve tip II diabetes mellitus gibi çeşitli durumlarla ilişkilendirilmiştir7. İrisinin artmış kardiyometabolik riskle ilişkili olmasının yanı sıra, irisin, akut miyokard infarktüsünde olası bir biyolojik belirteç olarak önerilmiştir ${ }^{8,9}$. Homosistein (Hcy), metiyonin metabolizması sonunda oluşan, yüksek oranda reaktif sülfür içeren bir amino asittir ve kardiyovasküler hastalıklar için bir risk faktörüdür. Hipotiroidi hastalarında ${ }^{10,11}$ homosistein düzeylerinin artması, yüksek oranda aterotrombotik vasküler hastalık, miyokard infarktüsü ve inme ile ilişkili bulunmuştur ${ }^{12}$. Tiroid fonksiyon bozukluğu, kardiyovasküler hastalıkların ilerlemesi için bir risk faktörüdür ${ }^{13-15}$. Bununla birlikte, tiroid disfonksiyonunun aracılık ettiği kalp yetersizliği hastalarının insidansı veya prognozu değiştirdiğini gösteren uzun vadeli çalışmalar yoktur ${ }^{16}$. Tiroid hormonları, bazal metabolik hızın düzenlenmesinde ve muhtemelen termogenezde önemli bir rol oynamaktadır. Ya da tersine, irisin tiroid fonksiyonlarını etkiliyor olabilir. Tiroid hormonlarl, merkezi ve periferik yollardan enerji tüketimini etkileyen mekanizmalara işaret etmektedir ${ }^{17}$. Bu çalışmanın amacl, $\mathrm{SH}$ hastalarında dolaşımdaki irisin ve homosistein düzeyleri arasındaki ilişkiyi ortaya koymaktır. 


\section{YÖNTEMLER}

\section{Hasta ve Calışma dizaynı}

$\mathrm{Bu}$ çalışmanın etik kurulu onayı, Ordu Üniversitesi Klinik Araștırmalar Etik Kurulu tarafindan 12/04/2018 tarihinde Karar No:2018/77 ile alınmıştır. (Etik kurul belgesi ek dosyalar içinde sunulmuştur) Çalışmamız, subklinik hipotiroidi hastalarını içeren tek merkezli, kesitsel (cross-sectional) bir çalışmadır. Temmuz 2018 ile Nisan 2019 tarihleri arasında yeni tanı konmuş, yaş aralığı, 22-62 olan Ordu Üniversitesi Araştırma ve Eğitim Hastanesinde Dahiliye Polikliniğimize başvuran toplam 40 hasta çalışmaya dahil edildi. Bu hastalar yeni tanı konulan hastalar olduğu için hiçbir ek tedavi (levotiroksin tedavisi gibi) uygulanmadı. Kontrol grubu da, yaş aralığı 20-63 yaş arasında olan 40 ötiroid sağlıklı bireyi içermekteydi.

Çalışmadan dişlanma kriterleri; diabetes mellitus (açlık glukoz > $126 \mathrm{mg} \mathrm{/} \mathrm{dL),}$ hipertansiyon (mevcut veya geçmiş antihipertansif ilaç kullanımı veya sistolik basıncin saptanması $140 \mathrm{mmHg}$ ve / veya diastolik basınç> $90 \mathrm{mmHg}$ ), dislipidemi (plazma LDL-kolesterol seviyeleri> $130 \mathrm{mg} /$ $\mathrm{dL}$, trigliserit düzeyleri> $150 \mathrm{mg} / \mathrm{dL}$ ), akut ve kronik böbrek hastalığı, koroner arter hastalığl, periferik arter hastalığı, otoimmün hastalıklar, diğer kronik hastalıklar veya maligniteleri olup, sigara veya alkol kullananların hiçbiri çalışmaya dahil edilmedi. Çalışmaya dahil edilme kriterleri ise 18 yaşından büyük olunması, hipotiroidi tanısı almış olunması ve benzer yaş grubunda sağlıklı kontrol olgularıdır. Çalışma, Ordu Üniversitesi Araştırma ve Eğitim Hastanesi'nin tıbbi etik kurulu tarafından onaylandı ve tüm katılımcılara yazılı onay verildi. Her bir hasta ve kontrol numunesi için beş mililitre ( $5 \mathrm{ml}$ ) kan numunesi Vacutainer $\AA$ tüplerinde toplandı ve yaklaşık 30 dakika süreyle bu tüplerde bekletildi. $\mathrm{Bu}$ kan örnekleri periferik venden alındı. Kan örnekleri daha sonra 3000 rpm'de
10 dakika santrifüj edildi. Biyokimya tüplerinin üst kısmında kalan serum örnekleri daha sonra biyokimyasal analizde kullanılmak üzere (-80 $\left.{ }^{0} \mathrm{C}\right)$ 'de saklandı.

\section{Homosistein, irisin ve TSH düzeylerinin belirlenmesi}

Serum homosistein ve irisin konsantrasyonları, üretici firmanın talimatları doğrultusunda Sunred marka Elisa kiti kullanılarak ölçüldü. (Homosistein; Katalog No: 201-12-5536, Irisin; Katalog No: 201-12-5328, Sunred biyolojik teknolojisi, Shanghai, China). Intra ve inter assay aralıkları, homosistein ve irisin için sırasıyla $<\% 10$ ve $<\% 12$ 'idi. Ordu Üniversitesi Tıbbi Biyokimya Laboratuvarında bulunan BioTek Instrument EL800 Mikroplayt okuyucu kullanılarak 450nm'de tüm örneklerin absorbansları ölçüldü. Homosistein ve irisin için birimler sırasıyla $\mathrm{nmol} / \mathrm{mL}$ ve $\mathrm{ng} / \mathrm{mL}$ olarak belirlendi. Serbest T3 (normal aralık: 2.5-4.4 pg/mL), serbest T4 (normal aralık: 0.54-1.24 ng/mL), TSH (normal aralık: 0.34-5.6 $\mu \mathrm{IU} / \mathrm{mL}$ ) seviyeleri, otoanalizör (Roche Diagnostics, İsviçre) Cobas e 601 kullanılarak kemilüminesans yöntemle ölçüldü.

\section{İstatistiksel Analiz}

Test sonuçları SPSS (Sosyal ve Fen için İstatistik Programı) $21.0 \quad$ istatistiksel yazılımında analiz edildi. Veriler normal dağılım için ortalama \pm standart sapma olarak gösterildi. Her bir grupta irisin, homosistein, TSH, FT3, FT4 düzeyleri dağılımı KolmogorovSmirnov testi ile hesaplandı. SH ve kontrol gruplarının karşılaştırması, normal dağılım için Student $\mathrm{t}$ testi ile yapıldı. İstatistiksel anlamlılık,

$\mathrm{p}<0.05$ olarak kabul edildi.

\section{SONUÇLAR}

$\mathrm{Bu}$ çalışmaya subklinik hipotiroidi nedeniyle dahiliye polikliniğimize başvurmuş 40 hasta dahil edildi. Bu grubumuz $21(\% 52,5)$ erkek ve $19(\% 47,5)$ kadın hastayı içermekte olup, yaş ortalaması $41.7 \pm 13.4$ (dağılım aralığı 25- 
62)'idi. Sağlıklı kontrol grubu $14(\% 49,1)$ erkek ve $26(\% 50,9)$ kadından oluşmakta olup, yaş ortalaması 37.1 \pm 14.3 (dağılım aralığı 20-63) idi.

Tablo I: Çalışma gruplarında laboratuvar parametrelerinin değerlendirilmesi

\begin{tabular}{|lccc|}
\hline Parametreler & $\begin{array}{c}\text { SH grubu } \\
\text { (n: 40) }\end{array}$ & $\begin{array}{c}\text { Kontrol } \\
\text { grubu } \\
\text { (n: 40) }\end{array}$ & $\begin{array}{c}\text { P } \\
\text { değeri }\end{array}$ \\
\hline Irisin (ng/mL) & $16.3 \pm 4.0$ & $12.8 \pm 3.3$ & 0.0001 \\
Homosistein (nmol/mL) & $17.3 \pm 5.4$ & $10.3 \pm 5.06$ & 0.0001 \\
& & & \\
TSH ( $\boldsymbol{\mu U} / \mathbf{m L})$ & $13.9 \pm 10.2$ & $1.84 \pm 0.9$ & 0.0001 \\
fT3 (pg/mL) & $2.73 \pm 0.68$ & $3.06 \pm 0.59$ & 0.027 \\
fT4 $(\mathbf{n g} / \mathbf{m L})$ & $0.97 \pm 0.41$ & $1.2 \pm 0.36$ & 0.001 \\
\hline
\end{tabular}

Veriler ort \pm std sapma olarak ifade edildi.

$\mathrm{P}$ değeri; Student $\mathrm{t}$ testine göre kontrol ve SH grupları arasındaki farkı göstermektedir.

Hasta ve kontrol gruplarının yaş parametresinin istatistiksel olarak değerlendirilmesinde Student T testi ve cinsiyet yüzdelerinin belirlenmesinde ise Ki-Kare testi kullanıldı. P değerleri sırasıyla; yaş için $\mathrm{p}=0.487$, cinsiyet için $\mathrm{p}=0.513$ bulundu ve gruplar arasında anlamlı fark olmadığı belirlendi.

Biyokimyasal parametrelerin $\mathrm{SH}$ ve kontrol gruplarındaki dağılımı Tablo 1'de gösterilmektedir. İki grubun karşılaştırılmasında, SH'li hastalarda kontrollere göre anlamlı derecede yüksek irisin, Hcy, TSH seviyeleri belirlendi (sırasıyla, $\mathrm{p}$ $=0.0001, \mathrm{p}=0.0001, \mathrm{p}=0.0001)$. Optimal diagnostik FNDC5 / Irisin, Hcy ve TSH kesilme noktası, AUC, alıcı işletim karakteristiği (ROC) eğri verilerine göre duyarlılık ve özgüllük Tablo 2'de gösterilmektedir. Irisin ve Hcy düzeyleri, TSH düzeyleriyle kıyaslandığında bunların TSH kadar spesifik ve sensitif olduğu gözlendi. (Tablo 2). Hasta ve kontrol gruplarındaki Irisin, TSH ve Hcy'nin, ROC analizi sonuçları Şekil 1'de gösterilmiştir. Buna ek olarak, Tablo 2 ve Şekil 1'de görüldüğü gibi irisin, Hcy düzeylerine kıyasla daha düşük hassasiyet ancak daha yüksek özgüllük göstermiştir. Şekil 2'de hasta grubunda irisin ve homosistein parametreleri arasındaki pozitif korelasyon gösterilmiştir ( $\mathrm{p}=$ $0.0001, r=0.525$ ).

Tablo II: TSH, Irisin, Homosistein ROC eğrisi analizleri

\begin{tabular}{|lcccc|}
\hline & AUC & $\begin{array}{c}\text { Cutoff } \\
\text { değeri }\end{array}$ & Sensitivite & Spesivite \\
\hline TSH & 0.961 & $>4.11$ & 89.5 & 100 \\
& $(0.889-0.992)$ & & $(75.2-97.1)$ & $(90.7-100)$ \\
İrisin & 0.750 & $>14.43$ & 69.7 & 86.1 \\
& $(0.631-0.846)$ & & $(51.3-84.4)$ & $(70.5-95.3)$ \\
Homosistein & 0.800 & $>13.53$ & 74.2 & 82.9 \\
& $(0.683-0.888)$ & & $(55.4-88.1)$ & $(66.4-93.4)$ \\
\hline
\end{tabular}

\section{TARTIŞMA}

Tiroid hormonlarının, kalp ve kan damarları üzerinde doğrudan etkileri vardır. $\mathrm{Bu}$ hormonların eksikliği, kardiyovasküler sistemin fonksiyonel bozukluklarına neden olur. Kalp atış hızı, kalp debisi ve sistemik vasküler dirençteki değişiklikler tiroid durumuyla yakından ilişkilidir ${ }^{18,19}$. Hipotiroidi (HO) ve $\mathrm{SH}$ en sık görülen endokrin bozukluklar arasında sayılır. Metabolik disfonksiyona neden olabilir ve kardiyovasküler hastalık riskini artırabilir ${ }^{20,21}$. İrisin, tip II diabetes mellitus, metabolik sendrom, insülin direnci, obezite, kronik böbrek hastalığı, anoreksiya nervoza ve hipotiroidizm dahil olmak üzere çok çeşitli hastalıklarla ilişkilendirildi. Ek olarak, irisin akut miyokard infarktüsünde olası bir biyobelirteç olarak önerilmektedir'9. Yapılan bazı çalışmalarda, hipotiroid hastalarında Hcy seviyesi artmış ${ }^{10,11}$ homosistein seviyeleri aterotrombotik vasküler hastalı riski, miyokard enfarktüsü ve inme riski ile ilişkilendirilmiştir. Irisin ve Hcy'nin kesişim noktaları, kardiyovasküler hastalık ve hipotiroididir.

Ates ve ark. hipotiroid hastalarında irisin düzeylerinin yükseldiğini bildirmiştir. $\mathrm{Bu}$ artış tiroid bezinin yapısal bozukluğundan kaynaklanmış olabilir. Tüm deneklerde, irisin düzeylerinin tiroid uyarıcı hormon (TSH) ile pozitif, serbest T4 ile negatif olarak korele olduğu tespit edilmiştir ${ }^{3}$. Aslında, Huh ve 
arkadaşları $\mathrm{da}^{22}$, bir irisin öncüsü olan FNDC5'in tiroid bezinde bulunduğunu göstermiş ve tiroid bezinin iltihaplanması durumunda, tahribattan sonra irisinin kan seviyelerinin artabileceğini öngörmüştür. Samy ve arkadaşları ${ }^{23}$, hipotiroidi hastalarında, irisin düzeylerinde artış olduğunu ve bu artışın oksidatif stres ve kas yaralanması ile ilişkili olabileceğini söylemiştir. Öte yandan, çeşitli çalışmalarda hipotiroidi hastalarında düşük serum irisin düzeyi bulunmuștur ${ }^{24-26}$. Ruchala ve ark., hipotiroidi hastalarının, hipertiroidi hastalarına göre daha düşük irisin düzeylerine sahip olduğunu göstermiştir ${ }^{24}$. Hipotiroidi hastalarında düşük serum irisin düzeyi, irisin serum kreatin kinaz düzeyi ile negatif korelasyon gösterdiği için kas hasarı ile ilişkili olabilir. Deneysel çalışmalarda, irisin ve tiroid hormonları arasında bir ilişki gözlenmemiş ancak her iki çalışmada da deneklerin normal tiroid fonksiyonları vardır27,28.

Araștırmamızda, Ateș, Huh ve Samy ve ark. çalışmalarında olduğu gibi hipotiroidi grubunda kontrol grubuna göre serum irisin düzeylerinin daha yüksek olduğunu bulundu. Ayrıca, serum irisin düzeylerinin TSH artışı ve fT4 azalması ile bağlantılı olarak arttı̆̆ını gözlemledik, Hcy ve irisin hasta grubunda pozitif korelasyon gösterdi (Şekil 2). İrisin ve Hcy düzeyleri, Şekil 1'de gösterilen TSH seviyelerine benzer şekilde sensitif ve spesifikti. Çoğu çalışma, kardiyovasküler hastalıklarda irisin ve Hcy seviyelerinin arttığını ve hipotiroidizm gibi tiroid fonksiyon bozukluğunu ilişkilendirdiğini gösterdi

Çalışmamızın ana kısıtlılığı, nispeten az sayıda hasta ve kontrolü kapsamasıdır. Ayrıca demografik değerler ve rutin laboratuvar bulguları sınırlıydı. Sadece parametreler yaş ve cinsiyet sayılarıl yaş ve cinsiyet verileri arasında anlamlı fark yoktu birbirine çok yakındı) değerlendirildi.

Çıkar Çatışması Beyanı: Yazarlar çıkar çatışması olmadığını bildirmişlerdir.
Finansal Destek: Bu çalışma Ordu Üniversitesi Bilimsel Araştırma Projesi (Proje No: 1814),tarafından desteklenmiştir.

\section{KAYNAKLAR}

1. Cojić M, Cvejanov-Kezunović L. Subclinical Hypothyroidism - Whether and When To Start Treatment. Maced J Med Sci. 2017; 15; 5: 1042-6.

2. Moreno-Navarrete JM, Ortega F, Serrano M, et al. Irisin is expressed and produced by human muscle and adipose tissue in association with obesity and insulin resistance. J Clin Endocrinol Metab. 2013; 98: E769-78.

3. Ateş İ, Altay M, Topçuoğlu C, Yılmaz FM. Circulating levels of irisin is elevated in hypothyroidism, a casecontrol study. Arch Endocrinol Metab. 2016; 60: 95100.

4. Zybek-Kocik A, Sawicka-Gutaj N, Wrotkowska E, Sowiński J, Ruchała M. Time-dependent irisin concentration changes in patients affected by overt hypothyroidism. Endokrynol Pol. 2016; 67: 476-80.

5. Iizuka K, Machida T, Hirafuji M. Skeletal muscle is an endocrine organ. J Pharmacol Sci 2014; 125: 125e131.

6. Hofmann T, Elbelt U, Stengel A. Irisin as a musclederived hormone stimulating thermogenesisea critical update. Peptides 2014; 54: 89e100.

7. Moreno M, Moreno-Navarrete JM, Serrano M, et al. Circulating irisin levels are positively associated with metabolic risk factors in sedentary subjects. PLoS One. 2015; 10: e0124100.

8. Panagiotou G, Mu L, Na B, Mukamal KJ, Mantzoros CS. Circulating irisin, omentin-1, and lipoprotein subparticles in adults at higher cardiovascular risk. Metabolism. 2014; 63: 1265-71.

9. Kuloglu T, Aydin S, Eren MN, et al. Irisin: a potentially candidate marker for myocardial infarction. Peptides. 2014; 55C: 85-91.

10. Morris MS, Bostom AG, Jacques PF, Selhub J, Rosenberg IH. Hyperhomocysteinemia and hypercholesterolemia associated with hypothyroidism in the third US National Health and Nutrition Examination Survey. Atherosclerosis. 2001; 155: 195200.

11. Bamashmoos SA, Al-Nuzaily MA, Al-Meeri AM, Ali FH. Relationship between total homocysteine, total cholesterol and creatinine levels in overt hypothyroid patients. Springerplus. 2013; 30: 423. 
12. Maron BA, Loscalzo J. The treatment of hyperhomocysteinemia. Annu Rev Med 2009; 60: 3954.

13. Selmer C, Olesen JB, Hansen ML,et al. Subclinical and overt thyroid dysfunction and risk of all-cause mortality and cardiovascular events: a large population study. J Clin Endocrinol Metab 2014; 99: 2372-82.

14. Nanchen D, Gussekloo J, Westendorp RG, et al. Subclinical thyroid dysfunction and the risk of heart failure in older persons at high cardiovascular risk. J Clin Endocrinol Metab 2012; 97: 852-61.

15. Gencer B, Collet TH, Virgini V, et al. Subclinical thyroid dysfunction and the risk of heart failure events: an individual participant data analysis from 6 prospective cohorts. Circulation 2012; 126: 1040-9.

16. Vargas-Uricoechea $\mathrm{H}$, Bonelo-Perdomo A. Thyroid Dysfunction and Heart Failure: Mechanisms and Associations. Curr Heart Fail Rep. 2017; 14: 48-58.

17. McAninch EA, Bianco AC. Thyroid hormone signaling in energy homeostasis and energy metabolism. Ann N Y Acad Sci. 2014; 1311: 77-87.

18. Zarković M. The deficit of thyroid hormones - effect on cardiovascular and cognitive functions. (srb. Deficit tiroidnih hormona - uticaj na kardiovaskularne i kognitivne funkcije.) Medical Gazette Special hospital for thyroid gland diseases and metabolic diseases Zlatibor (srb. Medicinski glasnik Specijalna bolnica za bolesti štitaste žlezde i bolesti metabolizma Zlatibor). 2007; 12: 47-53.

19. Klein I, Ojamaa K. Thyroid hormone and cardiovascular System. N Engl J Med. 2001; 344: 501-9.
20. Ichiki T. Thyroid hormone and atherosclerosis. Vascul Pharmacol. 2010; 52: 151-6.

21. Cappola AR, Ladenson PW. Hypothyroidism and atherosclerosis. J Clin Endocrinol Metab. 2003; 88: 2438-44.

22. Huh JY, Panagiotou G, Mougios V, et al. FNDC5 and irisin in humans: I.Predictors of circulating concentrations in serum and plasma and II. mRNA expression and circulating concentrations in response to weight loss and exercise. Metab Clin Exp 2012; 61: 1725-38.

23. Samy DM, Ismail CA, Nassra RA. Circulating irisin concentrations in rat models of thyroid dysfunction effect of exercise. Metabolism 2015; 64: 804-13.

24. Ruchala M, Zybek A, Szczepanek-Parulska E. Serum irisin levels and thyroid function - Newly discovered association. Peptides. 2014; 60: 51-5.

25. Yalcin MM, Akturk M, Tohma $Y$, et al. Irisin and myostatin levels in patients with Graves' disease. Arch Med Res 2016; 47: 471-5.

26. Zybek-Kocik A, Sawicka-Gutaj N, Wrotkowska E, Sowiński J, Ruchała M. Time-dependent irisin concentration changes in patients affected by overt hypothyroidism. Endokrynol Pol 2016; 67: 476-80

27. Ellefsen S, Vikmoen O, Slettaløkken G, et al. Irisin and FNDC5: effects of 12-week strength training, and relations to muscle phenotype and body mass composition in untrained women. Eur J Appl Physiol 2014: 114; 1875-88.

28. Stengel A, Hofmann $T$, Goebel-Stengel $M$, et al. Circulating levels of irisin in patients with anorexia nervosa and different stages of obesity - correlation with body mass index. Peptides 2013; 39: 125-30. 